\title{
Riboflavin Induces Disease Resistance in Plants by Activating a Novel Signal Transduction Pathway
}

\author{
H. Dong and S. V. Beer
}

Department of Plant Pathology, Cornell University, Ithaca, NY 14853.

Current address of H. Dong: Department of Plant Protection, Nanjing Agricultural University, Nanjing 210095, China. Accepted for publication 14 April 2000.

\begin{abstract}
Dong, H., and Beer, S. V. 2000. Riboflavin induces disease resistance in plants by activating a novel signal transduction pathway. Phytopathology 90:801-811.

The role of riboflavin as an elicitor of systemic resistance and an activator of a novel signaling process in plants was demonstrated. Following treatment with riboflavin, Arabidopsis thaliana developed systemic resistance to Peronospora parasitica and Pseudomonas syringae pv. Tomato, and tobacco developed systemic resistance to Tobacco mosaic virus (TMV) and Alternaria alternata. Riboflavin, at concentrations necessary

of pathogenesis-related (PR) genes in the plants, suggesting its ability to trigger a signal transduction pathway that leads to systemic resistance. Both the protein kinase inhibitor K252a and mutation in the NIM1/NPR1 gene which controls transcription of defense genes, impaired responsiveness to riboflavin. In contrast, riboflavin induced resistance and PR gene expression in NahG plants, which fail to accumulate salicylic acid (SA). Thus, riboflavin-induced resistance requires protein kinase signaling mechanisms and a functional NIMI/NPRI gene, but not accumulation of SA. Riboflavin is an elicitor of systemic resistance, and it triggers resistance signal transduction in a distinct manner.
\end{abstract} for resistance induction, did not cause cell death in plants or directly affect growth of the culturable pathogens. Riboflavin induced expression
Additional keywords: protein kinase cascade, systemic acquired resistance.
Two forms of induced resistance in plants, systemic acquired resistance (SAR), and induced systemic resistance (ISR), have been demonstrated. SAR refers to a distinct signal transduction pathway $(19,37,66,71,72)$ that is mediated by salicylic acid (SA) and activates defense genes, such as pathogenesis-related (PR) genes $(2,6,26,48,52,56,79,82)$. Transgenic Arabidopsis and tobacco plants (NahG) expressing the bacterial nahG gene, which encodes salicylate hydroxylase that degrades SA, are incapable of accumulating sufficient SA to induce SAR when challenged with pathogens $(21,29)$. For many SAR-inducing compounds identified, SA is one of several plant-derived substances that elicit SAR $(39,41,66)$. Several synthesized analogs of SA, such as 2,6dichloroisonicotinic acid (INA), mimic SA in resistance induction $(28,33,47,55,78)$. INA was an inducer of SAR in mutant screens, permitting discovery of a regulatory gene in SAR signal transduction known as NIMI (20,68), NPRl (9-11), or SAII (69). NIMI/NPRI encodes a protein that controls expression of various sets of defense genes $(8,10,16,40,65,88)$. Arabidopsis niml mutants fail to develop SAR following infection by pathogens and treatment with SAR inducers $(20,68)$. ISR, on the other hand, refers to resistance developed in plants following colonization by biocontrol rhizobacteria $(36,51,75,76)$. ISR is mediated by jasmonic acid (JA) and ethylene and is not associated with expression of the set of SAR-associated genes $(54,60,63,64)$. Although the pathways are different, both SAR and ISR require NIMI/NPRI for induction $(26,65)$.

Responses mediated by SA, JA, and ethylene suggest that these plant-derived substances have important physiological roles and great potential as elicitors and mediators of resistance signal transduction. All three compounds induce unique types of resis-

Corresponding author: S. V. Beer; E-mail address: svb1@ cornell.edu

Publication no. P-2000-0530-01R

(C) 2000 The American Phytopathological Society tance when topically applied, and they affect a variety of processes in plants, including environmental acclimatization and defense against pathogens and insect pests $(21,41,42,79,80,84,85)$. However, disease resistance may develop through alternative pathways that use different components. For example, oxidative burst (46) is an immediate response to inoculation with avirulent pathogens or treatment with resistance elicitors and leads to hypersensitive response (HR), a programmed cell death associated with disease resistance in plants $(3,18,38,72,74,77)$. The reaction involves complex redox processes that require participation by specific signal molecules, such as $\mathrm{H}_{2} \mathrm{O}_{2}(12,46)$, and nitric oxide $(22,50)$, and antioxidants, such as tocopherols and riboflavin $(62,74,84)$.

Riboflavin is a vitamin produced by plants and microbes that acts as a coenzyme in many physiological processes in animals, plants, and microbes $(30,34,83,90)$. Riboflavin is involved in antioxidation $(62,74)$ and peroxidation $(90)$; both processes affect the production of reactive oxygen intermediates (ROIs) in oxidative burst and consequent $\operatorname{HR}(3,18,22,38)$. Foliar application of riboflavin effectively controls several diseases of tobacco (25), and it reduces powdery mildew of strawberry plants in combination with methionine, metal ions, and surfactant (81). Thus, riboflavin may function as a resistance elicitor or a mediator of resistance signal transduction.

We report here evidence that riboflavin is an activator of a novel signaling pathway leading to systemic resistance. Riboflavin activates PR genes in Arabidopsis and tobacco and induces systemic resistance to four pathogens, including three model systems routinely used to study resistance $(17,19,66)$, suggesting that riboflavin initiates resistance signal transduction. The response to riboflavin is negated by the protein kinase inhibitor K252a and by mutation of the NIMI/NPRI gene, but is unaffected in NahG plants, demonstrating that riboflavin-triggered signaling requires protein kinases and regulation by NIM1/NPR1, but does not require accumulation of SA. These findings should stimulate studies of novel roles for riboflavin and novel mechanisms of resistance signal transduction in plants. 


\section{MATERIALS AND METHODS}

Plant growth and treatment. Tobacco cvs. NC89, Xanthi $(\mathrm{NN})$, and Xanthi (NN) containing the $n a h G$ gene from Pseudomonas putida $(21,29)$ were grown in the greenhouse. Arabidopsis thaliana accession Columbia (Col-O), transgenic Col-O containing $n a h G$, accession $\mathrm{Ws}-\mathrm{O}$, and $\mathrm{Ws}-\mathrm{O}$ niml-1 (hereafter niml) mutants were grown in a chamber at 18 to $20^{\circ} \mathrm{C}$ with $14 \mathrm{~h}$ of illumination. Six- to seven-week-old tobacco and two-week-old Arabidopsis plants were examined routinely for resistance induction. Plants were sprayed with water or $0.5 \mathrm{mM}$ riboflavin (Sigma-Aldrich Chemical Co., St. Louis, MO), unless stated otherwise. The SAR-inducing chemical 2,6-dichloroisonicotinic acid (INA, $0.125 \mathrm{mg} / \mathrm{ml})(55,78)$ and the HR-elicitor harpin $(15 \mu \mathrm{g} / \mathrm{ml})$ produced by Erwinia amylovora (23) were used as positive controls for PR gene expression and microscopic cell death. INA was provided as $25 \%$ wettable powder by K. Lawton, Novartis Crop Protection Inc. (Research Triangle Park, NC). Harpin was prepared and applied according to previous methods (23).

Pathogen maintenance and inoculation. Tobacco mosaic virus (TMV) was maintained in an aqueous solution $(18 \mathrm{mg} / \mathrm{ml})$ at $4^{\circ} \mathrm{C}$. A diluted solution of $1 \mu \mathrm{g} / \mathrm{ml}$ was used to inoculate leaves of tobacco (Xanthi) by rubbing the leaf lamina with a finger dipped in inoculum mixed with diatomaceous earth as an abrasive. Alternaria alternata was propagated on potato dextrose agar (PDA) plates at $27^{\circ} \mathrm{C}$ and maintained on slants at $4^{\circ} \mathrm{C}$. A spore suspension of $5 \times 10^{6}$ spores per $\mathrm{ml}$ was used to inoculate tobacco leaves by placing $25-\mu$ drops on six sites on the upper leaf surfaces of tobacco (NC89). Maintenance, propagation, and inoculation of Peronospora parasitica and Pseudomonas syringae pv. tomato DC3000 were done as described previously $(29,41,71)$. Col-O and NahG transgenic Arabidopsis were inoculated with the Peronospora parasitica isolate Noco2, and ecotype Ws-O and niml mutant plants were inoculated with Peronospora parasitica isolate Emwa1. All plant genotypes were inoculated with $P$. syringae pv. tomato DC3000 $(31,43)$. Inoculated plants were incubated as described, except those inoculated with the bacterium, which were kept at room temperature $\left(20\right.$ to $\left.23^{\circ} \mathrm{C}\right)$.

Responses of plants. Arabidopsis and tobacco plants were sprayed with riboflavin at $0,0.1,0.5,2.5,5.0,7.5$, and $10.0 \mathrm{mM}$, respectively. Plants were assessed for possible phytotoxicity caused by riboflavin. In addition, leaves of Arabidopsis were detached 6 days after treatment, stained with trypan blue in lactophenol, cleared with chloral hydrate solution, and examined under an Olympus BX60 microscope (Olympus Corporation, NY) for microscopic cell death, according to previous methods $(24,73)$.

Effects of riboflavin on pathogen growth. A. alternata was cultured on plates of PDA medium containing $0,0.1,0.5,2.5,5.0$, 7.5 , and $10.0 \mathrm{mM}$ riboflavin at $25^{\circ} \mathrm{C}$ for 7 days; diameters of the fungal colonies were measured. $P$. syringae was cultured in LuriaBertani medium containing equal concentrations of riboflavin on a shaker at $200 \mathrm{rpm}$ and $25^{\circ} \mathrm{C}$ for $20 \mathrm{~h}$. Cultures were started uniformly by adding $10 \mu \mathrm{l}$ of sterile water or $10 \mu \mathrm{l}$ of the seed culture suspension $\left(\approx 5 \times 10^{8} \mathrm{CFU} /\right.$ liter $)$. Relative populations of bacteria in the suspension cultures were estimated by measuring absorbance at $620 \mathrm{~nm}$ (31). Five replicates were done for each pathogen.

Evaluation of pathogen infection and disease resistance. Infection by TMV and $A$. alternata in tobacco was assessed 7 and 10 days after inoculation, respectively. The number of lesions per leaf was counted, and the diameters of 10 to 20 lesions per leaf were measured. Infection of Arabidopsis by Peronospora parasitica was judged based on growth of conidiospores on the leaves 5 to 7 days after inoculation; the percentage of infected plants was recorded, and the amount of conidiospores per leaf was estimated by counting conidiospores in leaf washes with a hemacytometer. Oomycete growth in leaves was examined after staining with lactophenol-trypan blue $(24,73)$. Infection by P. syringae in Arabidopsis was observed 5 to 7 days after inoculation; the bacterial populations in leaf tissues were determined by recovering bacteria from leaves of inoculated plants and dilution-plating according to previous methods (21).

To determine if resistance develops systemically, riboflavin or water was sprayed on the three lower leaves or infiltrated in intercellular leaf spaces of tobacco, and 5 days later two untreated upper leaves were inoculated with TMV or A. alternata. In Arabidopsis, riboflavin or water was infiltrated into intercellular leaf spaces of two lower leaves, followed 5 days later by inoculation of whole plants with Peronospora parasitica.

Each test was repeated three to five times, and each replicate contained 30 to 50 Arabidopsis seedlings or 25 to 50 viral or fungal lesions on tobacco leaves, unless specified otherwise. $F$ tests were done to determine any significant differences between treatments with riboflavin and water ( $F$ test two-sample for variances, Data Analyses Tools, Microsoft Excel Software).

Northern blot analyses. mRNA corresponding to $P R-1$ and $P R-2$ in Arabidopsis and $P R-1 a$ in tobacco was assessed in treated plants by northern blot hybridization. Plants for RNA analyses were treated with caution to prevent spraying the apices and the youngest three leaves. Total RNA was isolated from the untreated, youngest leaves with the RNeasy plant mini kit (Qiagen, Chatsworth, CA). RNA was size-fractionated by agarose gel electrophoresis and transferred to Immobilon transfer membrane (Millipore Corp., Bedford, MA), as described previously $(15,82)$. Replicate blots of RNA from Arabidopsis and tobacco were hybridized to ${ }^{32} \mathrm{P}[\mathrm{dCTP}]$-labeled Arabidopsis $P R-1$ and $P R-2$ probes and tobacco acidic $P R-1 a$ probe, respectively. Hybridized membranes were washed at high stringency (13). For Arabidopsis and tobacco, 4 and $8 \mu \mathrm{g}$ of total RNA per lane was used, respectively. Uniform loading was verified by staining with ethidium bromide.

Determination of effects of K252a. The protein kinase inhibitor K252a (Calbiochem, Novabiochem International Inc., San Diego, CA) was applied by spraying at $25 \mathrm{~nm}$ on a single leaf of tobacco or whole plants of Arabidopsis $30 \mathrm{~min}$ after treatment with riboflavin or water. The development of resistance and expression of PR genes in the treated plants was assessed as above. To determine if K252a alone affects infection and PR gene expression, plants of Arabidopsis treated only with K252a were tested for infection and PR gene expression.

\section{RESULTS}

Riboflavin-induced resistance in Arabidopsis. Reduction in infection by the downy mildew pathogen, Peronospora parasitica, was observed in Arabidopsis after treatment with riboflavin, as compared with water treatment. Differences in degree of infection between treatments were determined (Fig. 1A). In plants treated with water, Peronospora parasitica caused heavy infection in both accessions (Col-O and Ws-O) within 5 days, evidenced by heavy growth of hyphae and oospores in leaf tissues, as shown by microscopy of trypan blue-stained leaves. By day 7, massive numbers of conidiospores covered leaf surfaces. In riboflavin-treated plants, the pathogen did not produce visible masses of conidiospores on leaf surfaces but was restricted to leaf margins and a few small interior islands, as indicated by staining with trypan blue. Based on conidiospores per leaf, water-treated plants supported production of a large number of spores, while riboflavintreated plants had only $\approx 0.1 \%$ of the number on water-treated plants during the same period (Fig. 2A). In addition, the number of infected plants treated with riboflavin was significantly lower than those treated with water 12 days after inoculation (Fig. 3A). Therefore, riboflavin-induced resistance to the oomycete pathogen was demonstrated qualitatively based on the obvious reduction in infection and quantitatively by reduction in conidiospores produced per leaf and percentage of infected plants.

The occurrence of chlorosis and necrosis in Arabidopsis inoculated with $P$. syringae pv. tomato DC3000 was reduced by 
treatment with riboflavin (Fig. 1B). The degree of infection was also evaluated based on the amount of bacteria recovered from leaf tissues daily for 5 days following inoculation. At each time, the number of bacteria recovered from control plants was significantly higher than that recovered from plants treated with riboflavin (Fig. 2B). Thus, riboflavin effectively induced resistance to the bacterial pathogen.

Riboflavin-induced resistance in tobacco. Tobacco plants treated with riboflavin developed resistance to A. alternata and TMV, based on reduced numbers and smaller diameters of lesions that developed following inoculation with the fungus or virus (Fig. 1C, Table 1). The degree of reduction in lesion numbers and diameters following riboflavin application was different for the two pathogens. In plants inoculated with TMV, riboflavin treatment significantly reduced the number of lesions. Lesion diameter was also reduced in riboflavin-treated plants, but the reduction was not always statistically significant (Table 1). In plants inoc- ulated with $A$. alternata, reductions in both numbers and diameters of brown spot lesions were similar. Seven days after inoculation, brown spot lesions in water-treated plants were generally $\approx 10 \mathrm{~mm}$ in diameter, while lesions in riboflavin-treated plants were only $\approx 3 \mathrm{~mm}$ in diameter (Fig. 2C). Based on the reduction in lesion diameter, riboflavin-induced resistance was more effective against $A$. alternata than TMV (Fig. 2C and D).

Kinetics of riboflavin-induced resistance. Resistance in Arabidopsis to Peronospora parasitica and $P$. syringae and resistance in tobacco to TMV and A. alternata developed systemically throughout the plants, based on the reduction in the degree of infection on the untreated upper plant parts following treatment of lower leaves with riboflavin (Fig. 2, Table 1).

According to the time course of pathogen growth in the plant tissues, resistance in riboflavin-treated Arabidopsis became apparent after 3 days, reached its highest level at 5 days, and declined quickly 9 days after treatment (Fig. 3A and B). The time

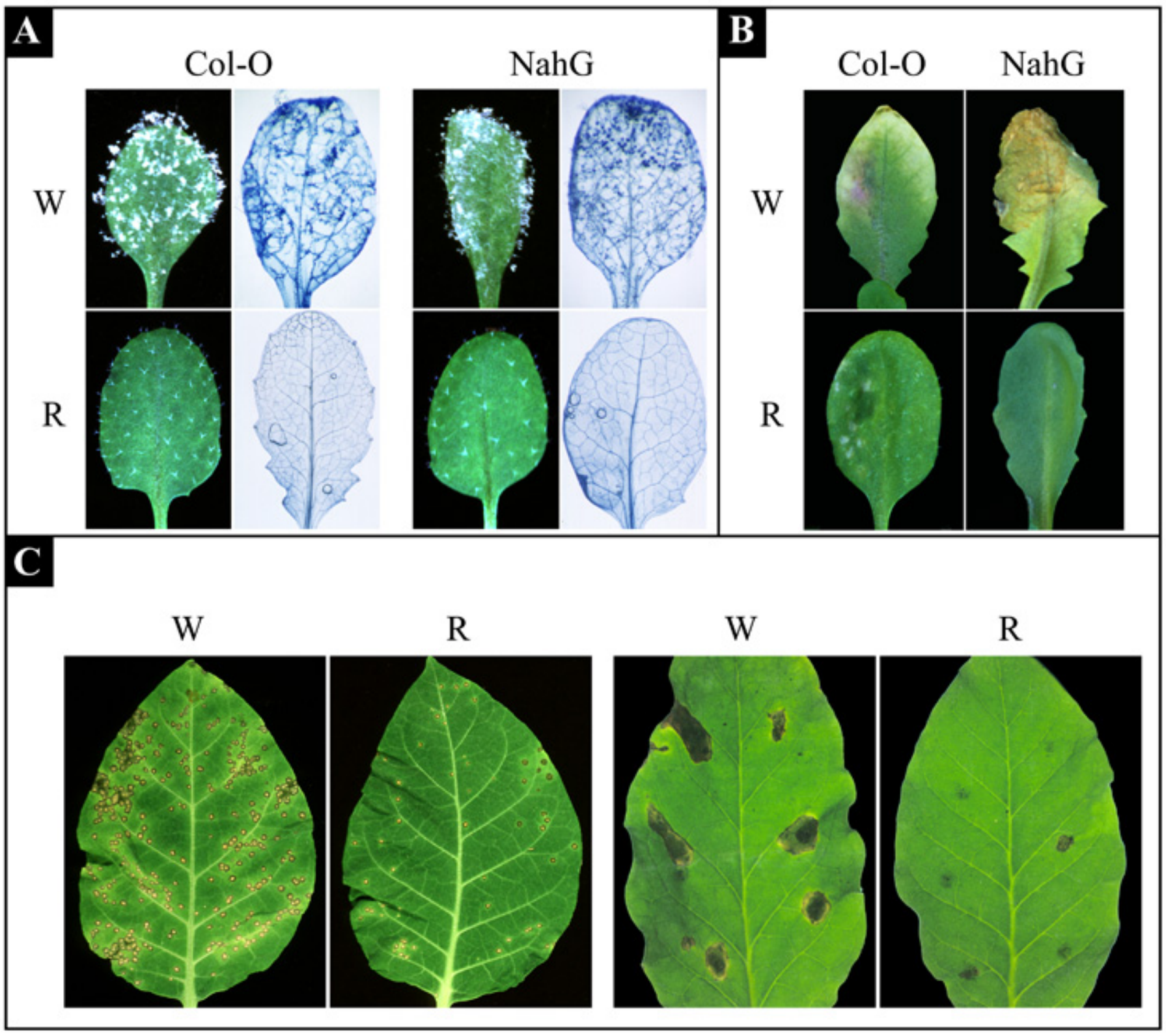

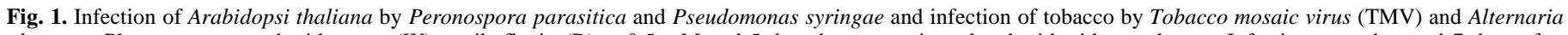

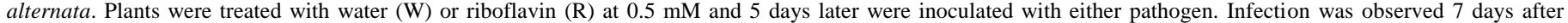

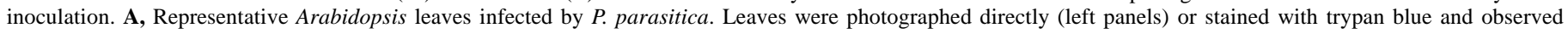

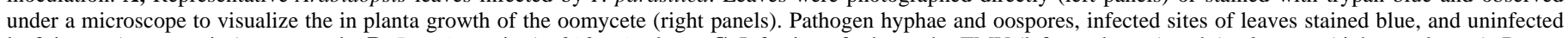

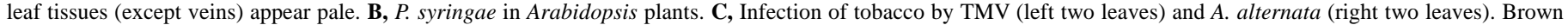
spots caused by $A$. alternata were covered with spores. 
course of development of resistance to TMV and A. alternata in tobacco plants was similar. Resistance became apparent after 5 days and reached its highest level at 10 to 12 days after treatment (Fig. 3B). However, the duration of resistance to both pathogens differed. Brown spot symptoms were reduced for 40 days posttreatment, while diameters and numbers of TMV lesions were no longer reduced after 20 days, based on periodical inoculation at intervals up to 40 days posttreatment (Fig. 3B; data not shown).

Effects of riboflavin on plants and pathogens. The dose effect of riboflavin showed that concentrations of 0.5 to $1 \mathrm{mM}$ were effective and sufficient for resistance induction; higher concentrations did not increase the effect (Fig. 4). To determine the possibility of phytotoxicity, plants were treated with 0.1 to $10 \mathrm{mM}$ riboflavin. Treated leaves did not exhibit any necrosis or other abnormalities when examined macroscopically or microscopically (Fig. 5). On the other hand, the effect of riboflavin on the growth of $A$. alternata and $P$. syringae was determined in vitro by growth of the pathogens in media supplemented with riboflavin ranging from 0 to $10 \mathrm{mM}$. Both pathogens grew well at all concentrations, indicated by the similar colony diameters of the fungal cultures on
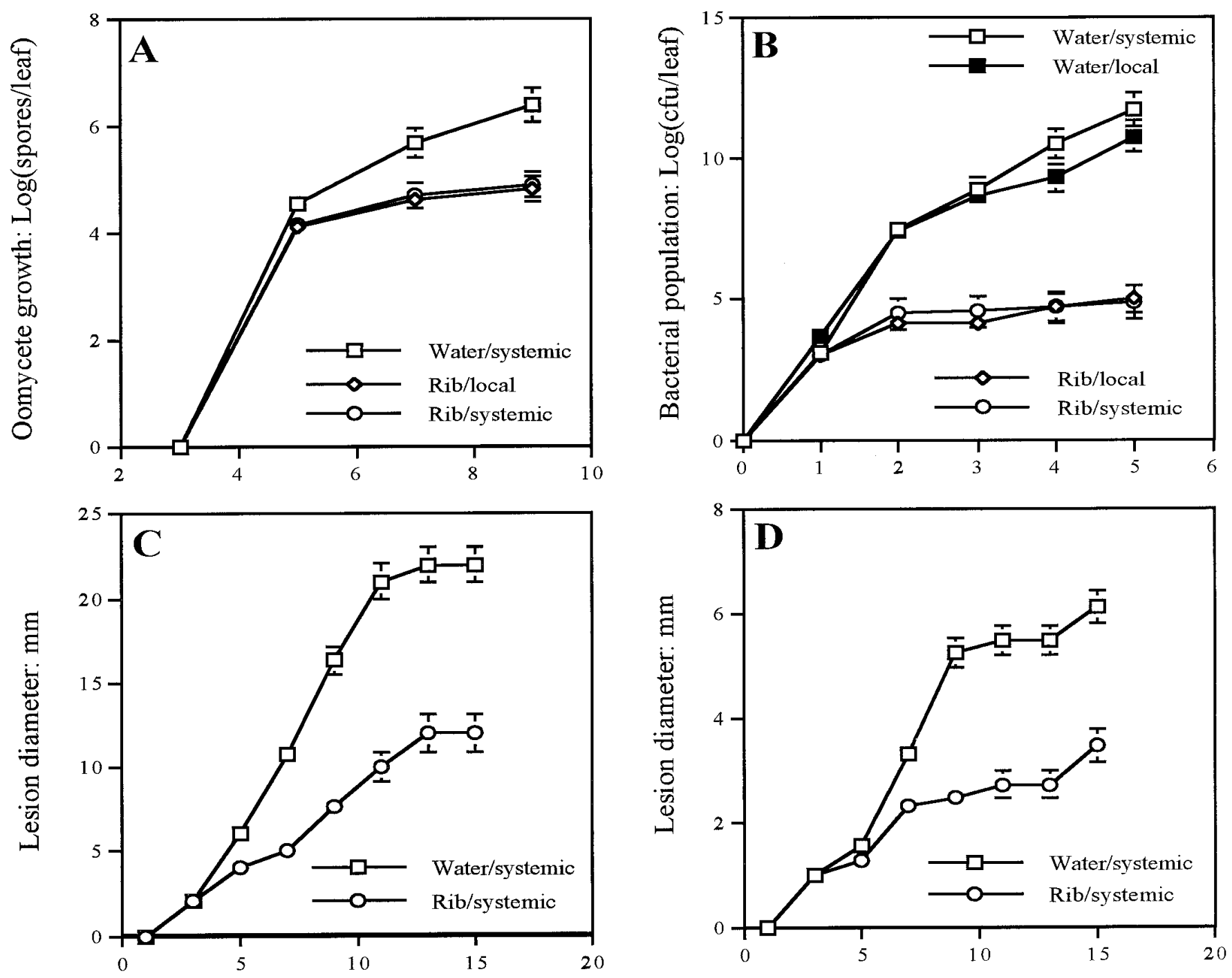

Days after inoculation

Days after inoculation

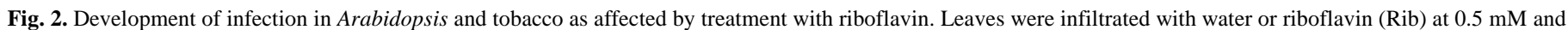

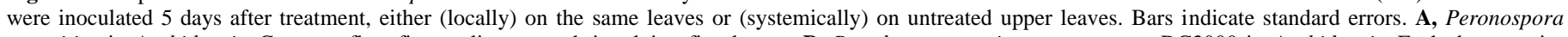

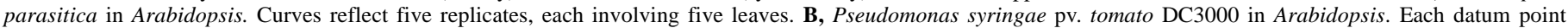

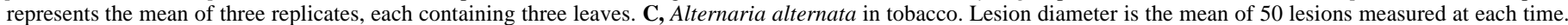
D, Tobacco mosaic virus in tobacco. Lesion diameter is the mean of 48 lesions measured at each time point.

TABLE 1. Tobacco mosaic virus infection in wild-type and NahG Xanthi tobacco plants treated with water and riboflavin

\begin{tabular}{|c|c|c|c|c|c|}
\hline \multirow[b]{2}{*}{ Treatment } & \multirow[b]{2}{*}{ Leaf ${ }^{y}$} & \multicolumn{2}{|c|}{ Wild-type ${ }^{z}$} & \multicolumn{2}{|c|}{$\mathrm{NahG}^{\mathrm{z}}$} \\
\hline & & No. of lesions per leaf & Lesion diameter (mm) & No. of lesions per leaf & Lesion diameter $(\mathrm{mm})$ \\
\hline \multirow[t]{2}{*}{ Water } & Treated & $185 \pm 8(\mathrm{~A})$ & $6.6 \pm 0.5(\mathrm{~A})$ & $290 \pm 15(\mathrm{~A})$ & $7.5 \pm 0.5(\mathrm{~A})$ \\
\hline & Upper & $170 \pm 10(\mathrm{~A})$ & $5.3 \pm 0.3(\mathrm{~A})$ & $255 \pm 25(\mathrm{~A})$ & $7.8 \pm 0.8(\mathrm{~A})$ \\
\hline \multirow[t]{2}{*}{ Riboflavin } & Treated & $91 \pm 16(\mathrm{~B})$ & $5.0 \pm 0.5(\mathrm{~A})$ & $115 \pm 30(\mathrm{~B})$ & $5.0 \pm 0.7(\mathrm{~B})$ \\
\hline & Upper & $77 \pm 14(\mathrm{~B})$ & $3.1 \pm 0.2(\mathrm{~B})$ & $140 \pm 20(\mathrm{~B})$ & $5.2 \pm 1.0(\mathrm{~B})$ \\
\hline
\end{tabular}

y Water or riboflavin was sprayed on lower leaves (treated) of plants. Seven days later, the upper two leaves were inoculated.

${ }^{\mathrm{z}}$ Lesions were examined 10 days after inoculation. Numbers followed by the same letter within columns do not differ significantly at $P \leq 0.05$. 
agar plates and the similar absorbance values of the bacterial suspension cultures, respectively (Table 2).

Activation of PR genes. Arabidopsis and tobacco plants treated with riboflavin or water were tested for expression of PR genes by northern blot hybridization. Accumulation of transcripts of $P R-1$ and $P R-2$ genes were detected in the untreated upper leaves of the two accessions of Arabidopsis, in which the lower leaves had been treated with riboflavin 2 days prior to RNA extraction. Level of PR gene expression was estimated based on visual intensity of bands from northern blot hybridizations (Fig. 6A and B). Expression of both $P R-1$ and $P R-2$ increased with time after treatment, but their patterns of expression over the course of the experiment were slightly different. Transcription of $P R-1$ was evident at 2 days and reached its highest level 4 days after treatment with riboflavin. Expression of $P R-2$ increased slightly from 2 to 6 days (Fig. 6A) in tobacco. Similar, expression of $P R-1 a$ was detected in the untreated upper leaves of plants on which the lower leaves had been treated with riboflavin (Fig. 6C). In Arabidopsis and tobacco, treatment with INA, an elicitor of SAR, induced levels of PR gene expression similar to treatment with riboflavin, while treatment with water did not induce detectable expression of PR genes (Fig. 6).
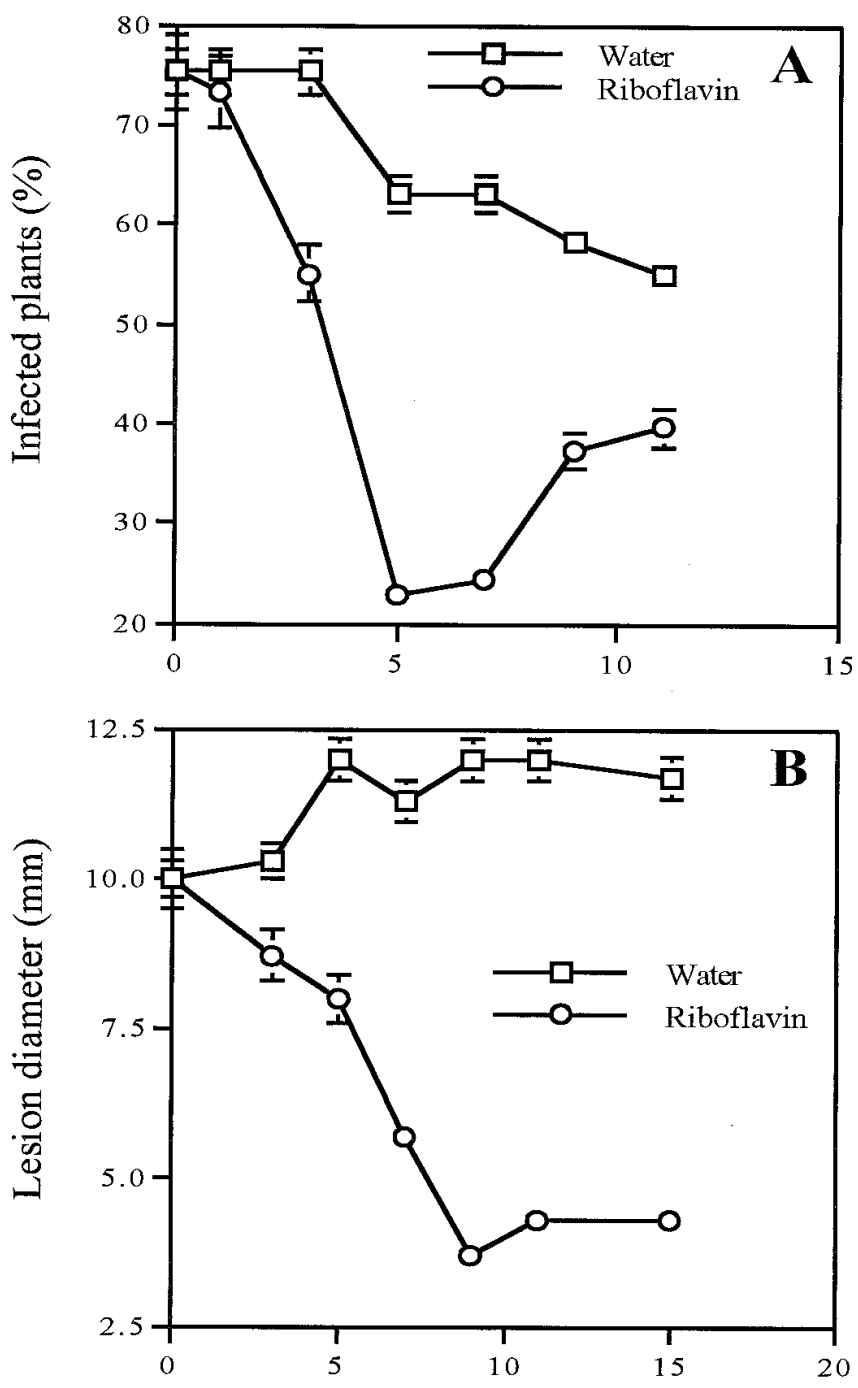

Inoculation time (days after treatment)

Fig. 3. Effect of time between treatment with water or riboflavin and inoculation on development of infection by A, Peronospora parasitica in Arabidopsis, and $\mathbf{B}$, Alternaria alternata in tobacco. Infection was examined 7 days after inoculation. Data at each time represents means (plus/minus standard errors) from 90 to 150 Arabidopsis seedlings or 75 to 150 lesions.
Impairment by K252a of resistance and PR gene expression. In tobacco, application of protein kinase inhibitor K252a after treatment with riboflavin greatly reduced riboflavin-induced resistance to TMV and A. alternata (Fig. 7A). Plants treated with water and inoculated with the virus or fungus developed large brown spots or viral lesions. K252a alone slightly increased
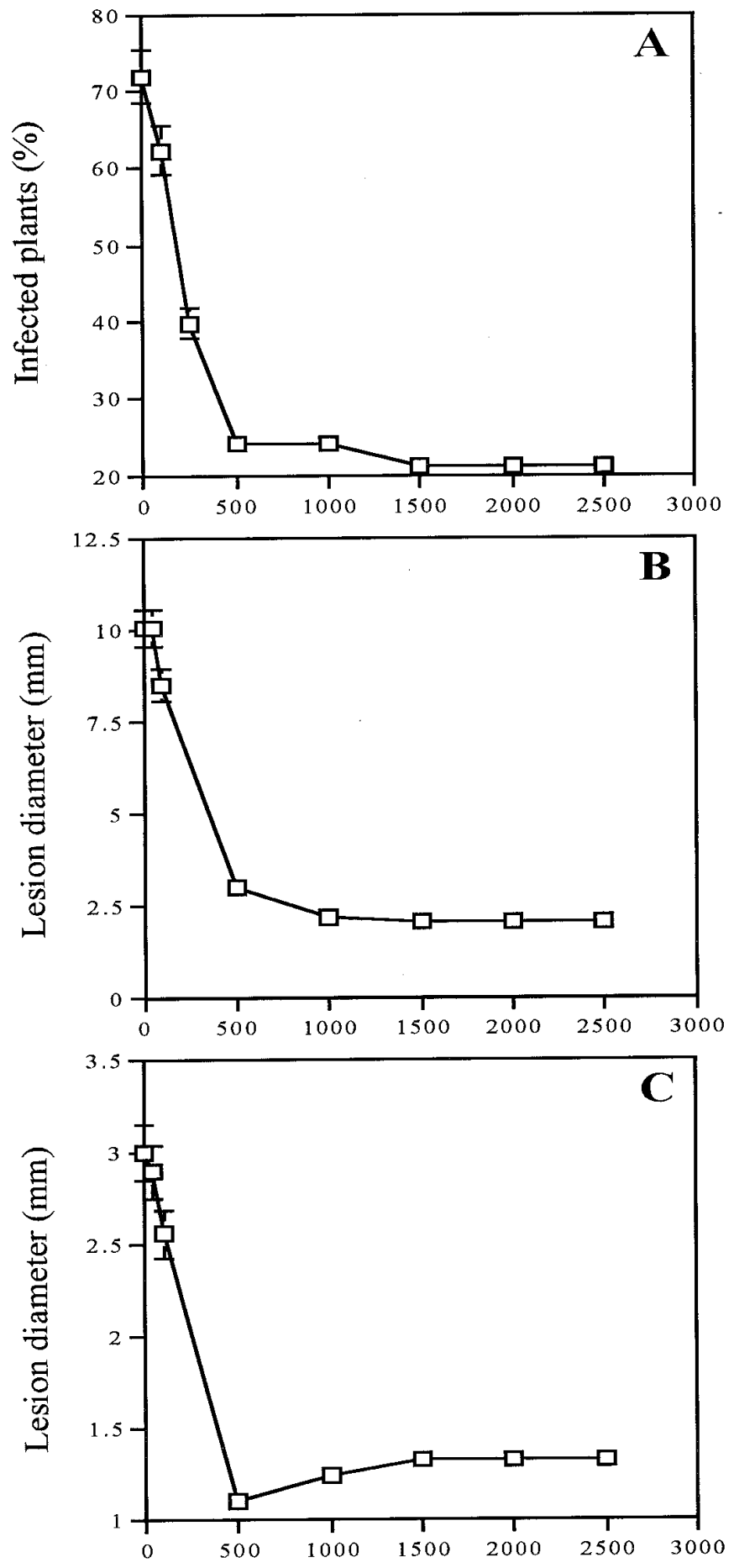

Concentration of riboflavin (micromole)

Fig. 4. Effects of concentration of riboflavin on the development of infection by A, Peronospora parasitica in Arabidopsis, B, Alternaria alternata in tobacco, and $\mathbf{C}$, Tobacco mosaic virus in tobacco. Plants were sprayed with water or riboflavin and inoculated 5 days after treatment. Infection was evaluated 7 days (A and C) and 10 days (B) after inoculation. Each datum point represents the mean (plus/minus standard errors) of three replicates, involving $\mathbf{A}, 30$ to 50 Arabidopsis seedlings; B, 30 to 50 lesions; and C, 50 lesions. 


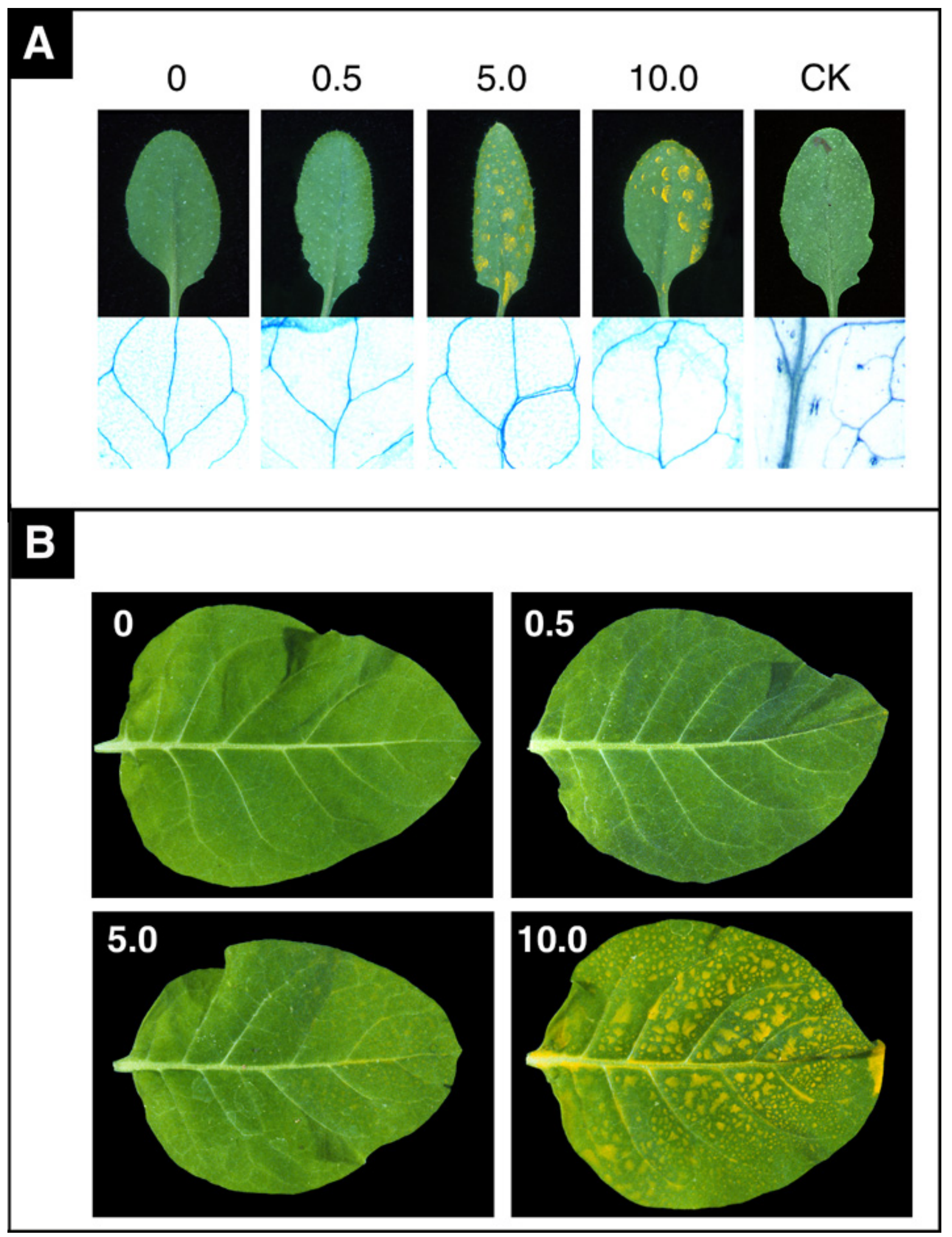

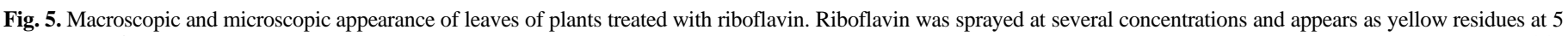

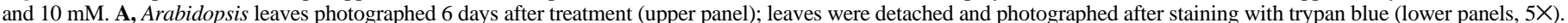
Trypan blue stains nectrotic cells of the CK leaf, which had been treated with harpin that induces micro-HR $(3,24)$. B, Tobacco leaves photographed 7 days after treatment. 
susceptibility of tobacco to both pathogens, based on diameters of spots and lesions. Riboflavin reduced fungal and viral necrosis diameters by $\approx 60$ and $\approx 40 \%$, respectively. However, addition of K252a to riboflavin-treated plants reduced the effect of riboflavin by $\approx 80 \%$, based on lesion diameters.

The role of riboflavin in resistance induction in Arabidopsis similarly was affected by K252a (Fig. 7B). K252a alone slightly increased infection by Peronospora parasitica in Col-O but not in Ws-O. Riboflavin reduced infection by $\approx 45$ and $\approx 60 \%$ in Ws-O and Col-O, respectively. Subsequent application of K252a to riboflavin-treated plants evidently obviated the effects of riboflavin.

Northern blot hybridization indicated that riboflavin-activated PR gene expression also was counteracted by K252a (Fig. 6A and C). Thus, the protein kinase inhibitor concomitantly inhibits the role of riboflavin in inducing resistance and activating PR gene expression.

Induction of resistance and PR gene expression in NahG plants. To determine if accumulation of SA is necessary for induction of resistance and PR gene expression by riboflavin, NahG Arabidopsis and tobacco were treated and examined as were nontransgenic plants. Induction of both resistance and PR gene expression occurred in NahG plants (Figs. $1 \mathrm{~A}$ and $\mathrm{B}$, and $6 \mathrm{~B}$ and $\mathrm{C}$ ). In riboflavin-treated NahG Arabidopsis, growth of Peronospora parasitica was greatly reduced (Fig. 1A), and fewer plants were infected (Fig. 8); P. syringae did not cause obvious symptoms, similar to what occurred in the wild-type (Fig. 1B). In NahG tobacco, the numbers and diameters of lesions caused by TMV were significantly decreased by treatment with riboflavin (Table 1). Arabidopsis $P R-1$ and $P R-2$ genes and tobacco $P R-1 a$ gene were expressed in NahG plants following treatment with riboflavin (Fig. 6B and C). Therefore, riboflavin is able to induce resistance and activate defense genes in the absence of SA accumulation.

Compromise of resistance and PR gene expression in nim1 Arabidopsis. To determine if a functional NIMI/NPRl gene is required for the action induced by riboflavin, Arabidopsis niml mutants were examined for resistance development and PR gene expression following application of riboflavin. No PR gene expression was detected in niml mutant plants (Fig. 6B). The mutant also failed to develop resistance after treatment with riboflavin (Fig. 8). Both the wild-type and niml mutant supported growth of a number of conidiospores on leaf surfaces when treated with water (control), but niml plants were more sensitive to the pathogen (Fig. 8). Resistance developed in wild-type plants but did not develop in niml plants after treatment with riboflavin. A similar percentage of infection was observed in niml plants, whether treated with water or riboflavin. These data suggest a requirement for regulation by the NIMI/NPRl gene in the induction of resistance by riboflavin.

\section{DISCUSSION}

The terminology used for different types of resistance in plants (to infection by pathogens) has become quite confusing. Subtle

TABLE 2. Effect of riboflavin on growth in vitro of Alternaria alternata and Pseudomonas syringae pv. tomato DC3000

\begin{tabular}{lcc}
\hline $\begin{array}{l}\text { Riboflavin } \\
\text { concentration }(\mathrm{mM})\end{array}$ & $\begin{array}{c}\text { A. alternata colony } \\
\text { diameter }(\mathrm{cm})^{\mathrm{z}}\end{array}$ & $\begin{array}{c}\text { Relative growth of } \\
\text { DC3000 }\left(\mathrm{OD}_{620}\right)^{\mathrm{z}}\end{array}$ \\
\hline 0 & $2.4 \pm 0.2$ & $2.03 \pm 0.03$ \\
0.1 & $2.3 \pm 0.2$ & $2.23 \pm 0.03$ \\
0.5 & $2.4 \pm 0.1$ & $2.23 \pm 0.04$ \\
1.0 & $2.3 \pm 0.3$ & $2.22 \pm 0.07$ \\
2.5 & $2.4 \pm 0.1$ & $1.88 \pm 0.04$ \\
5.0 & $2.5 \pm 0.1$ & $1.79 \pm 0.04$ \\
7.5 & $2.3 \pm 0.3$ & $1.75 \pm 0.08$ \\
10.0 & $2.3 \pm 0.2$ & $1.68 \pm 0.04$ \\
\hline
\end{tabular}

y Optical density (OD) at $620 \mathrm{~nm}$.

${ }^{\mathrm{z}}$ Each number represents the mean of five replicates. changes in modifiers or word order in combination with "induced" and "resistance" have been proposed to indicate resistances induced by specific biological, chemical, or physical factors. Often these subtleties are lost or hard to express in conversation or translation to languages other than English. Therefore, we propose that the term "induced resistance" be used generally to encompass resistant plant phenotypes that result from any treatments that cause plants to develop resistance, which is not constitutive. The inducer of the resistance can precede the "induced resistance" to clearly define the process. For example, SA-induced resistance $(52,66)$, Plant growth promoting rhizobacteria-induced resistance (51), harpin-induced resistance $(23,24)$, and, based on the present report, riboflavin-induced resistance. More specific terms, such as "the SAR pathway" (66) and "the ISR pathway" $(65,75)$, are used to refer to a specific signal transduction process leading to the phenotype of induced resistance to a specific array of pathogens.

The studies reported here indicate that treating plants with riboflavin results in pathogen resistance, which differs from previously described types of resistance; the process requires plant metabolism time between treatment and the development of resistance. Thus, clearly it is a form of induced resistance. Comparison of riboflavin-induced resistance with several previously described types indicated that riboflavin induces resistance specifically by a novel mechanism involving a pathway that differs from those studied previously.
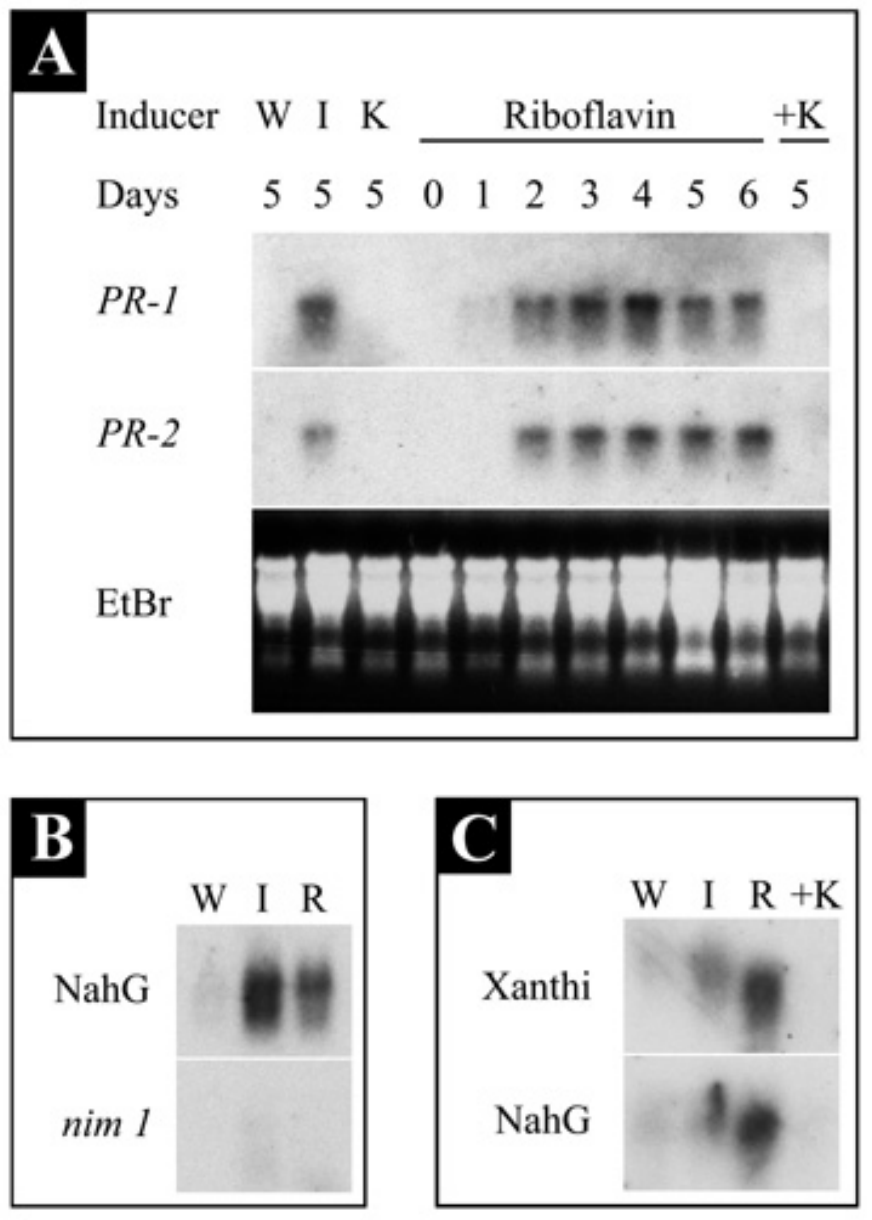

Fig. 6. Northern blot hybridization showing riboflavin-induced pathogenesisrelated gene expression as affected by plant genotype and application of K252a. Plants were treated with $\mathrm{W}=$ water; $\mathrm{I}=$ positive control 2,6-dichloroisonicotinic acid at $0.125 \mathrm{mg} / \mathrm{ml} ; \mathrm{K}=$ protein kinase inhibitor $\mathrm{K} 252 \mathrm{a}$ at $25 \mathrm{mM}$; $\mathrm{R}=$ riboflavin at $0.5 \mathrm{mM}$; or $+\mathrm{K}=$ riboflavin followed by K252a. RNA was extracted from the untreated upper leaves at days indicated after treatment. Uniform loading was verified by staining with ethidium bromide (EtBr). A, Transcripts of $P R-1$ and $P R-2$ from Arabidopsis (ecotype Col-O). B, Expression of PR-1 in Arabidopsis NahG transgenic but not in niml mutant plants 5 days after treatment. C, Expression of $P R-1 a$ in tobacco (Xanthi) and NahG plants 5 days after treatment. 
Basis of the hypothesis that riboflavin induces resistance through activating plant defense mechanism. The important role of riboflavin (vitamin $\mathrm{B}_{2}$ ) as an indispensable vitamin for healthy animals and as an effective therapeutic treatment for many physiological diseases in animals and humans $(34,59,83)$ inspired external application of the vitamin to plants. Although plants can synthesize riboflavin themselves, levels of riboflavin vary greatly in organs and during stages of development $(70,90)$. Riboflavin is an antioxidant $(62,74)$, and other antioxidants induce disease re-
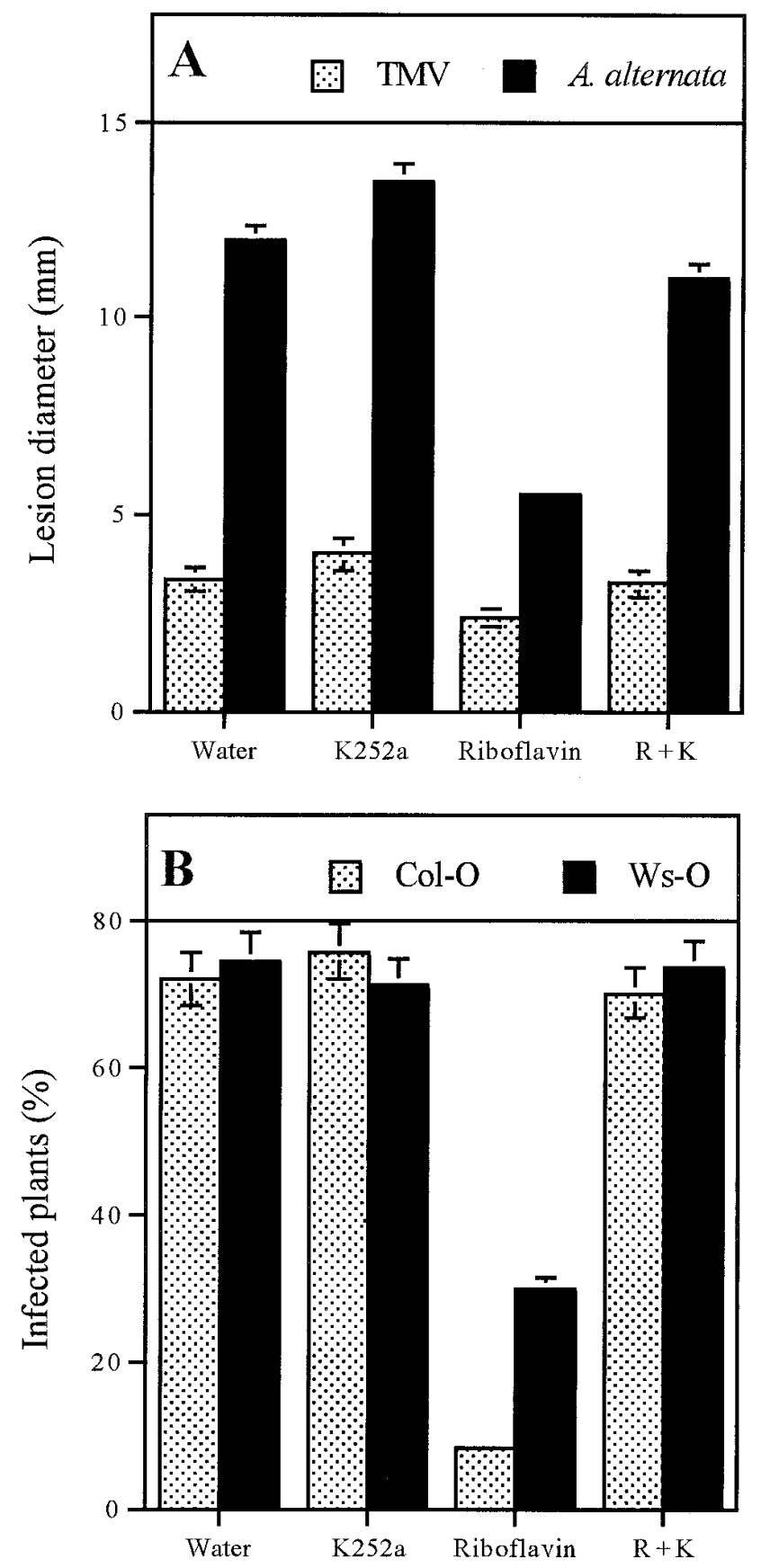

Treatment

Fig. 7. Effect of K252a on the ability of riboflavin to induce resistance in tobacco and Arabidopsis. Plants were treated with water, K252a at $25 \mathrm{mM}$, riboflavin at $0.5 \mathrm{mM}$ separately, or pretreated with riboflavin at $0.5 \mathrm{mM}$ for $30 \mathrm{~min}$ followed by K252a (R+K). A, Infection by Tobacco mosaic virus (TMV) or Alternaria alternata in tobacco; and $\mathbf{B}$, infection by Peronospora parasitica in Arabidopsis was evaluated based on lesion diameters and percentage of infected plants, respectively. Error bars indicate variations from means of three replicates. sistance in plants (61). These features are consistent with the concept that riboflavin might play a role in plant disease resistance.

In this study, we first determined the development and kinetics of resistance in Arabidopsis and tobacco following application of riboflavin. We ruled out the possibility that riboflavin might directly inhibit pathogens. We analyzed PR gene expression to determine if riboflavin is capable of triggering a resistance signaling process. We determined resistance and PR gene expression in several plant genetic backgrounds and in the presence of a general inhibitor of protein kinases to reveal the nature of the riboflavintriggered signal transduction process. Microscopic observation of leaf tissues stained with trypan blue was used to visualize the growth of Peronospora parasitica in plant tissues. This method also allowed visualization of microscopic cell death, either as a consequence of riboflavin signaling responses, which could occur within $24 \mathrm{~h}$ as usual, or due to possible phytotoxicity of riboflavin, which might occur within several days $(23,24,73)$. Both molecular and phenotypic data showed that riboflavin substantially induced systemic disease resistance and did so by activating a distinct signal transduction pathway.

Practical value of riboflavin as an elicitor of disease resistance. Our studies demonstrate that riboflavin elicits systemic resistance. This conclusion is supported by data showing development of resistance in Arabidopsis and tobacco against four pathogens, three of which represent the established spectrum of targets of induced resistance $(35,44,66,71)$. In addition, no direct affect of the vitamin was detected on the growth of the culturable pathogens, suggesting that riboflavin is not likely to directly inhibit pathogens. Riboflavin-induced resistance was effective against $A$. alternata, which has not yet been considered as a target of induced resistance $(35,44,66)$.

As previous studies $(25,61,62,74,81)$ indicate, riboflavin has potential for practical use. Resistance-inducing chemicals have been applied for disease control, but success has been limited thus far $(39,44,66)$. For example, SA and INA are not feasible for dis-

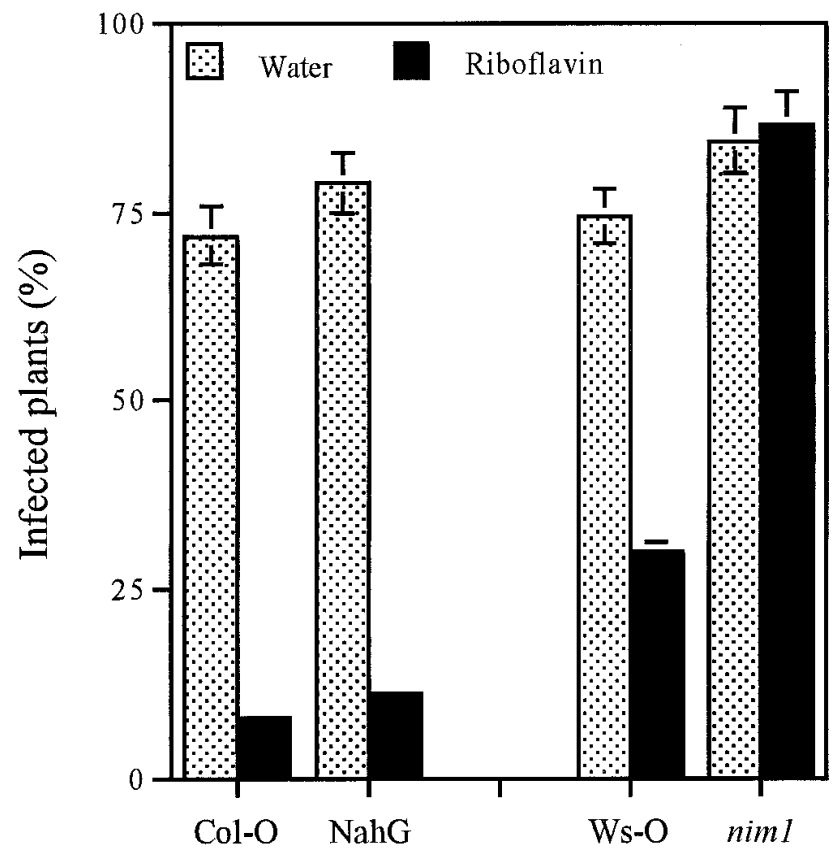

Genotype

Fig. 8. Effect of riboflavin treatment on infection by Peronospora parasitica of Arabidopsis transgenic NahG and niml mutant plants. Plants were sprayed with water or riboflavin $(0.5 \mathrm{mM})$ and inoculated 5 days after treatment. Degree of infection was evaluated 7 days after inoculation. Bars represent the means of three replicates, each containing 30 to 50 seedlings. 
ease control, because the concentration needed to induce resistance is nearly phytotoxic (66). In contrast, our studies suggest that riboflavin is not phytotoxic at concentrations much higher than that needed for resistance induction. The level of riboflavininduced resistance, though not total, would seem to be useful. In our experiments, treatment of tobacco plants with riboflavin reduced the diameters of brown spot lesions from $\approx 10$ to $\approx 3 \mathrm{~mm}$ in most cases. This lesion reduction caused an obvious increase in the quality and commercial value of flue-cured tobacco leaves (25). During flue-curing performed after harvest, the nectrotic areas of lesions on leaves greatly enlarge. Also, it may alter chemical components, including the levels of sugars, proteins, nicotine, potassium, and chlorides, which are negatively affected by diseases. Even smaller reductions in lesion size on fresh leaves could result in greater commercial value of cured leaves. Riboflavin enhances resistance in Arabidopsis and tobacco by 40 to $70 \%$, a level that should provide worthwhile protection to crops against pathogens. Further, riboflavin-induced resistance is persistent, as it continues to be effective against A. alternata in tobacco for 40 days. Finally, riboflavin-induced resistance is nonspecific and can provide a basis for protection to a broad range of plants against an array of pathogens. Therefore, riboflavin seems to possess many important characteristics of a safe disease control agent.

Riboflavin activation of a distinct signal transduction pathway. Our studies also indicate that riboflavin triggers resistance signal transduction in a distinct manner. First, expression of PR genes is considered a downstream event of resistance signal transduction that leads to phenotypic resistance $(2,6,67,86,88)$. The genes activated by riboflavin are involved in activation of resistance induced by other factors (66). The kinetics of riboflavininduced resistance reflect the requirement for accumulation of molecular defense components $(32,35,44)$, thus, PR gene expression took 4 to 5 days to reach its highest level and preceded the greatest phenotypic resistance. This is consistent with previous studies that showed that external application of riboflavin promotes certain physiological processes in plants $(30,57)$. For example, addition of riboflavin to suspension-cultured cells of strawberry enhances synthesis of anthocyanin, a universal plant pigment that has pharmacological effects (57). Second, because $\mathrm{K} 252 \mathrm{a}$, a protein kinase inhibitor, inhibited the ability of riboflavin to induce resistance and defense gene expression, riboflavin appears to act through a signaling process that involves protein kinases $(7,27)$. Finally, because resistance and PR gene expression were induced in NahG transgenic but not in niml mutant plants, responsiveness to riboflavin requires regulation by the NIM1/NPR1 gene but is independent of SA. Based on these data, we conclude that riboflavin induces nonspecific disease resistance by triggering a novel signal transduction pathway that appears distinct from the typical SAR and ISR pathways.

The riboflavin-initiated signal transduction pathway appears to cross-talk with the ISR pathway at NIMI/NPRI and with the SAR pathway from NIMI/NPRI to PR gene activation. However, it is distinct from the traditional SAR and ISR pathways in several respects. The SAR signal transduction pathway is characterized by coordinate activation of SAR genes, including PR genes, with the development of resistance $(5,53,66,82)$, and SAR is dependent on SA accumulation (29). ISR is distinct from SAR, although both require regulation by the $N I M I / N P R I$ gene and lead to nonspecific resistance $(36,51,54,60,75,76)$. ISR is mediated by different signals and is not associated with expression of the battery of SAR-related genes $(63-65,80,85)$. Although mitogen-activated protein kinases are induced by SA, the contribution of the kinases in SAR and ISR pathways is not clear (87). Unlike many SAR elicitors, such as harpin $(23,24)$, which induces hypersensitive cell death as a necessary step in the development of SAR $(18,66)$, riboflavin does not cause macroscopic and microscopic cell death in plants at concentrations that effectively induce resis- tance. Thus, riboflavin activates resistance mechanisms in a HRindependent manner.

Possible riboflavin-mediated resistance signal transduction links. The identified signal molecules that mediate resistance development in plants show three characteristics $(22,41,42,79,80$, 84,85): (i) they induce disease resistance when applied exogenously; (ii) they activate a signal transduction process when applied exogenously; and (iii) they are synthesized and mediate resistance signal transduction when plants are infected by pathogens or treated with resistance elicitors. We have shown that external application of riboflavin elicits resistance and initiates a signal transduction process. How could the signal transduction events occur in plants in response to riboflavin, for which physiological roles have been well demonstrated? Further, whether riboflavin functions as a mediator of resistance signal transduction remains an interesting question.

Recent studies of riboflavin $(1,3,34,46,49,62,70,74,90)$ indicates the function of the compound in mediating resistance signal transduction. First, riboflavin is a cofactor of enzyme flavoproteins, some of which catalyze lipid perioxidation (90), a main process in producing ROIs that serve as a signaling network in plant immune responses $(3,46)$. The role of riboflavin in perioxidation is antagonistic to its role in antioxidation $(62,74,90)$. Balance between both reactions should be a part of the signaling mediation and may affect whether programmed cell death occurs. Second, receptors or binding proteins of riboflavin are thought to serve as a storage mechanism for the vitamin in animals and animal products $(1,49)$. Exploration of the existence of similar receptors and their roles as signal transducers in plants responding to riboflavin and other elicitors of resistance would be very worthwhile. Third, glycosylated forms of riboflavin, which are considered unimportant in plant and animals $(34,70)$, may serve as a signal-storage compound. This function may be similar to that of calmodulins $(14,45)$ and glycosylated SA (41), which function in the $\mathrm{Ca}^{+2}$ and SA signal storage, respectively. Finally, the universal existence of flavin kinases, required to activate flavoproteins (90), may be linked with protein kinase cascades, which are a typical mode of signal transduction $(4,58,89)$. Therefore, there is a reasonable basis for riboflavin to mediate a distinct signal transduction pathway. We hope that this report will stimulate additional studies of the novel roles of riboflavin and mechanisms of resistance signal transduction in plants.

\section{ACKNOWLEDGMENTS}

This research was supported by the U.S. Department of Agriculture Special Grant 99-34367-7390 and Eden Bioscience Corporation (Bothell, WA). We thank K. Lawton, Novartis Crop Protection Inc. (Research Triangle Park, NC), for the gifts of 2,6-dichloroisonicotinic acid, NahG tobacco, and Arabidopsis. We also thank our colleague T. P. Delaney for providing Arabidopsis nim1-1 seeds, helpful instruction in microscopic observation and use of his visualization facilities, and for critically reviewing the manuscript. We thank J. M. Bonasera for helpful suggestions on the manuscript and K. Loeffler for the photos.

\section{LITERATURE CITED}

1. Adiga, P. R. 1994. Riboflavin carrier protein in reproduction. Pages 137176 in: Vitamin Receptors, Vitamins as Ligands in Cell Communication. K. Dakshinamurti, ed. Cambridge University Press, Cambridge.

2. Alexander, D., Goodman, R. M., Gut-Rella, M., Glascock, C., Weymann, K., Friedrich, L., Maddox, D., Ahl Goy, P., Luntz, T., Ward, E., and Ryals, J. 1993. Increased tolerance to two Oomycete pathogens in transgenic tobacco expressing pathogenesis-related protein 1a. Proc. Natl. Acad. Sci. USA 90:7327-7331.

3. Alvarez, M. E., Pennell, R. I., Meijer, P.-J., Ishikawa, A., Dixon, R. A., and Lamb, C. 1998. Reactive oxygen intermediates mediate a systemic signal network in the establishment of plant immunity. Cell 92:773-784.

4. Baker, B., Zambryski, P., Staskawicz, B., and Dinesh-Kumar, S. P. 1997. Signaling in plant-microbe interactions. Science 276:726-733.

5. Beffa, R., and Meius, F. Jr. 1996. Pathogenesis-related functions of plant 
$\beta$-1,3-glucanases investigated by antisense transformation: A review. Gene 179:97-103.

6. Bol, J. F., Linthorst, H. J. M., and Cornelissen, B. J. C. 1990. Plant pathogenesis-related proteins induced by virus infection. Annu. Rev. Phytopathol. 28:113-138.

7. Boller, T., and Felix, G. 1996. Olfaction in plants: Specific perception of common microbial molecules. Pages 1-9 in: Biology of Plant-Microbe Interactions. G. Stacey, B. Mullin, and P. M. Gresshof, eds. International Society for Molecular Plant-Microbe Interactions, St. Paul, MN.

8. Bowling, S. A., Clarke, J. D., Liu, Y., Klessig, D. F., and Dong, X. 1997. The cpr5 mutant of Arabidopsis expresses both NPRI-dependent and NPRI-independent resistance. Plant Cell 9:1573-1584.

9. Cao, H., Bowling, S. A., and Dong, X. 1994. Characterization of an Arabidopsis mutant that is nonresponsive to inducers of systemic acquired resistance. Plant Cell 6:1583-1592.

10. Cao, H., Glazebrook, J., Clarke, J. D., Volko, S., and Dong, X. 1997 The Arabidopsis NPR1 gene that controls systemic acquired resistance encodes a novel protein containing ankyrin repeats. Cell 88:57-63.

11. Cao, H., Li, X., and Dong, X. 1998. Generation of broad-spectrum disease resistance by overexpression of an essential regulator gene in systemic acquired resistance. Proc. Natl. Acad. Sci. USA 95:6531-6536.

12. Chamnongpol, S., Willekens, H., Moeder, W., Langebartels, C., Sandermann, H., Montagu, M. V., Inzé, D., and Camp, W. V. 1998. Defense activation and enhanced pathogen tolerance induced by $\mathrm{H}_{2} \mathrm{O}_{2}$ in transgenic tobacco. Proc. Natl. Acad. Sci. USA 95:5818-5823.

13. Church, G. M., and Gilbert, W. 1984. Genomic sequencing. Proc. Natl. Acad. Sci. USA 81:1991-1995.

14. Clapham, D. E. 1995. Calcium signaling. Cell 80:259-268.

15. Clark, M. S. 1997. Plant Molecular Biology, A Laboratory Manual. Springer-Verlag, Berlin.

16. Clarke, J. D., Liu, Y., Klessig, D. F., and Dong, X. 1998. Uncoupling PR gene expression from NPRI and bacterial resistance: Characterization of the dominant Arabidopsis cpr6-1 mutant. Plant Cell 10:557-569.

17. Dangl, J. L. 1993. Application of Arabidopsis thaliana to outstanding issues in plant-pathogen interactions. Int. Rev. Cytol. 144:53-83.

18. Dangl, J. L., Dietrich, R. A., and Richberg, M. H. 1996. Death don't have no mercy: Cell death programs in plant-microbe interactions. Plant Cell 8:1793-1807.

19. Delaney, T. P. 1997. Genetic dissection of acquired resistance to disease. Plant Physiol. 113:5-12.

20. Delaney, T. P., Friedrich, L., and Ryals, J. A. 1995. Arabidopsis signal transduction mutants defective in chemically and biologically induced disease resistance. Proc. Natl. Acad. Sci. USA 92:6602-6606.

21. Delaney, T. P., Uknes, S., Vernooij, B., Friedrich, L., Weymann, K., Negrotto, D., Gaffney, T., Gut-Rella, M., Kessmann, H., Ward, E., and Ryals, J. 1994. A central role of salicylic acid in plant disease resistance. Science 266:1247-1250.

22. Delledonne, M., Xia, Y., Dixon, R. A., and Lamb, C. 1998. Nitric oxide functions as a signal in plant disease resistance. Nature 394:585-588.

23. Dong, H., Delaney, T. P., Bauer, D. W., and Beer, S. V. 1999. Harpin induces disease resistance in Arabidopsis through the systemic acquired resistance pathway mediated by salicylic acid and the NIMI gene. Plant J. 20:207-215.

24. Dong, H., Delaney, T. P., and Beer, S. V. 1999. Harpin elicits concomitant microscopic hypersensitive response and systemic acquired resistance in plants. Page 45 in: Abstr., Mol. Plant-Microbe Interact. 9th Int. Congr. International Society for Molecular Plant-Microbe Interactions, St. Paul, MN.

25. Dong, H., Liu, A., Wang, Y., Liu, B., Fan, H., Liu, G., Wang, R., Chen, J., Sun, Y., Zhang, L., Qian, Y., Gao, Z., Xu, Q., Sun, X., and Sang, C. 1995. Control of brown spot by induced resistance in tobacco: Preparation SRS2, its functions to control the disease and to improve qualitative and economic properties of the cured leaves. Pages 422-427 in: Induced Resistance Against Diseases in Plants. H. Dong, ed. Science Press, Beijing.

26. Dong, X. 1998. SA, JA, ethylene, and disease resistance in plants. Curr. Opin. Plant Biol. 1:316-323.

27. Felix, G., Grosskopf, D. G., Regenass, M., and Boller, T. 1991. Rapid changes in protein phosphorylation are involved in transduction of the elicitor signal in plant cells. Proc. Natl. Acad. Sci. USA 88:8831-8834.

28. Friedrich, L., Lawton, K., Dincher, S., Winter, A., Staub, T., Uknes, S., Kessmann, H., and Ryals, J. 1996. Benzothiadiazole induces systemic acquired resistance in tobacco. Plant J. 10:61-70.

29. Gaffney, T., Friedrich, L., Vernooij, B., Negrotto, D., Nye, G., Uknes, S., Ward, E., Kessmann, H., and Ryals, J. 1993. Requirement of salicylic acid for the induction of systemic acquired resistance. Science 261:754-756.

30. Gastaldi, G., Laforenza, U., Gasirola, D., Ferrari, G., Tosco, M., and Rindi, G. 1999. Energy depletion differently affects membrane transport and intracellular metabolism of riboflavin taken up by isolated rat en- terocytes. J. Nutr. 129:406-409.

31. Gerhardt, P., Murray, R. G. E., Costilow, R. N., Nester, E. W., Wood, W. A., Krieg, N. R., and Phillips, G. B. 1981. Manual of Methods for General Bacteriology. American Society for Microbiology, Washington, D.C.

32. Goodman, M. N., Kiraly, Z., and Wood, K. R. 1986. Biochemistry and Physiology of Plant Disease. University of Missouri Press, Columbia.

33. Görlach, J., Volrath, S., Knauf-Beiter, G., Hengy, G., Beckhove, U., Kogel, K.-H., Oostendorp, M., Staub, T., Ward, E., Kessmann, H., and Ryals, J. 1996. Benzothiadiazole, a novel class of inducers of systemic acquired resistance, activates gene expression and disease resistance in wheat. Plant Cell 8:629-643.

34. Gregory, J. F., III. 1998. Nutritional properties and significance of vitamin glycosides. Annu. Rev. Nutr. 18:277-296.

35. Hammerschmidt, R., and Kuć, J. 1995. Induced Resistance to Disease in Plants. Kluwer Academic Publishers, Dordrecht, Netherlands.

36. Hoffland, E., Pieterse, C. M. J., Bik, L., and Pelt, A. 1995. Induced systemic resistance in radish is not associated with accumulation of pathogenesis-related proteins. Physiol. Mol. Plant Pathol. 46:309-320.

37. Hutcheson, S. W. 1998. Current concepts of active defense in plants. Annu. Rev. Phytopathol. 36:59-90.

38. Jabs, T., Dietrich, R. A., and Dangl, J. F. 1996. Initiation of runaway cell death in an Arabidopsis mutant by extracellular superoxide. Science 273:1853-1856.

39. Kessmann, H., Staub, T., Hofmann, C., Maetzke, T., Herzog, J., Ward, E., Uknes, S., and Ryals, J. 1994. Induction of systemic acquired resistance in plants by chemicals. Annu. Rev. Phytopathol. 32:439-459.

40. Kim, H. S., and Delaney, T. P. 1999. Isolation and characterization of NIM1-interacting proteins from Arabidopsis thaliana. Page 162 in: Abstr., Mol. Plant-Microbe Inter. 9th Int. Congr. International Society for Molecular Plant-Microbe Interactions, St. Paul, MN.

41. Klessig, D. F., and Malamy, J. 1994. The salicylic acid signal in plants. Plant Mol. Biol. 26:1439-1458.

42. Knoester, M., van Loon, L. C., van den Heuvel, J., Hennig, J., Bol, J. F., and Linthorst, H. J. M. 1998. Ethylene-insensitive tobacco lacks nonhost resistance against soil-borne fungi. Proc. Natl. Acad. Sci. USA 95:19331937.

43. Koncz, C., Chua, N.-H., and Schell, J. 1992. Methods in Arabidopsis Research. World Scientific Press, Singapore.

44. Kuć, J. 1982. Induced immunity to plant disease. BioScience 32:854-860.

45. Lai, Y., Nairn, A. C., and Greengard, P. 1986. Autophosphorylation reversibly regulates the $\mathrm{Ca}^{2+} /$ calmodulin-dependence of $\mathrm{Ca}^{2+} /$ calmodulin-dependent protein kinase II. Proc. Natl. Acad. Sci. USA 83:42534257.

46. Lamb, C., and Dixon, R. A. 1997. The oxidative burst in plant disease resistance. Annu. Rev. Plant Physiol. Plant Mol. Biol. 48:251-275.

47. Lawton, K., Friedrich, L., Hunt, M., Weymann, K., Delaney, T. P., Kessmann, H., Staub, T., and Ryals, J. 1996. Benzothiadiazole induces disease resistance in Arabidopsis by activation of the systemic resistance signal transduction pathway. Plant J. 10:71-82.

48. Lawton, K., Weymann, K., Friedrich, L., Vernooij, B., Uknes, S., and Ryals, J. 1995. Systemic acquired resistance in Arabidopsis requires salicylic acid but not ethylene. Mol. Plant-Microbe Interact. 8:863-870.

49. Lee, C. M., and White, H. B., III. 1996. Riboflavin-binding protein induces early death of chicken embryos. J. Nutr. 126:523-528.

50. Lincoln, J., Hoyle, C. H. V., and Burnstock, G. 1997. Nitric Oxide in Health and Disease. Cambridge University Press, Cambridge.

51. Liu, L., Kloepper, J. W., and Tuzun, S. 1995. Induction of systemic resistance in cucumber against angular leaf spot by plant growthpromoting rhizobacteria. Phytopathology 85:843-847.

52. Malamy, J., Carr, J. P., Klessig, D. F., and Raskin, I. 1990. Salicylic acid: A likely endogenous signal in the resistance response of tobacco to viral infection. Science 250:1002-1004.

53. Malamy, J., Sànchez-Casas, P., Hennig, J., Guo, A., and Klessig, D. F. 1996. Dissection of the salicylic acid signaling pathway in tobacco. Mol. Plant-Microbe Interact. 9:474-482.

54. Manners, J. M., Penninckx, I. A. M. A., Vermaere, K., Kazan, K., Brown, R. L., Morgan, A., Maclean, D. J., Curtis, M. D., Cammue, B. P. A., and Broekaert, W. F. 1998. The promoter of the plant defense in gene PDF1.2 from Arabidopsis is systemically activated by fungal pathogens and responds to methyl jasmonate but not to salicylic acid. Plant Mol. Biol. 38:1071-1080.

55. Métraux, J.-P., Ahl-Goy, P., Staub, T., Speich, J., Steinemann, A., Ryals, J., and Ward, E. 1991. Induced resistance in cucumber in response to 2,6-dichloroisonicotinic acid and pathogens. Pages 432-439 in: Advances in Molecular Genetics of Plant-Microbe Interactions, vol. 1. H. Hennecke and D. P. S. Verma, eds. Kluwer Academic Publishers, Dordrecht, Netherlands.

56. Métraux, J.-P., Signer, H., Ryals, J., Ward, E., Wyss-Benz, M., Gaudin, J., Raschdorf, K., Schmid, E., Blum, W., and Inverardi, B. 1990. Increase 
in salicylic acid at the onset of systemic acquired resistance in cucumber. Science 250:1004-1006.

57. Mori, T., and Sakurai, E. 1996. Riboflavin affects anthocyanin synthesis in nitrogen culture using strawberry suspended cells. J. Food Sci. 61:698-702.

58. Mulligan, B. M., Chory, J., and Ecker, J. R. 1997. Signaling in plants. Proc. Natl. Acad. Sci. USA 94:2793-2795.

59. National Research Council. 1989. Recommended Dietary Allowances. 10th ed. National Academy Press, Washington, DC.

60. Niki, T., Mitsuhara, I., Seo, S., Ohtsubo, N., and Ohashi, Y. 1998. Antagonistic effect of salicylic acid and jasmonic acid on the expression of pathogenesis-related (PR) protein genes in wounded mature tomato leaves. Plant Cell Physiol. 39:500-507.

61. Norris, D. M. April 1991. Methods for inducing resistance in plants using environmentally safe antioxidants. U.S. Patent No. 5,004,493.

62. Packer, L., Podda, M., Kitazawa, M., Thiele, J., Saliou, C., Witt, E., and Traber, M. G. 1996. Vitamin E and the metabolic antioxidant network. Pages 283-304 in: Molecular Mechanisms of Signaling and Membrane Transport. K. W. A. Wirtz, ed. Springer-Verlag, Berlin.

63. Penninckx, I. A. M. A., Eggermont, K., Terras, F. R. G., Thomma, B. P. H. J., De Samblanx, G. W., Buchala, A., Métraux, J.-P., Manners, J. M., and Broekaert, W. F. 1996. Pathogen-induced systemic activation of a plant defensin gene in Arabidopsis follows a salicylic acid-independent pathway. Plant Cell 8:2309-2323.

64. Pieterse, C. M. J., Van Wees, S. C. M., Hoffland, E., Van Pelt, J. A., and Van Loon, L. C. 1996. Systemic resistance in Arabidopsis induced by biocontrol bacteria is independent of salicylic acid accumulation and pathogenesis-related gene expression. Plant Cell 8:1225-1237.

65. Pieterse, C. M. J., Van Wees, S. C. M., Van Pelt, J. A., Knoester, M., Laan, R., Gerrits, H., Weisbeek, P. J., and Van Loon, L. C. 1998. A novel signaling pathway controlling induced systemic resistance in Arabidopsis. Plant Cell 10:1571-1580.

66. Ryals, J. A., Neuenschwander, U. H., Willits, M. G., Molina, A., Steiner, H.-Y., and Hunt, M. D. 1996. Systemic acquired resistance. Plant Cell 8:1809-1819.

67. Ryals, J., Uknes, S., and Ward, E. 1994. Systemic acquired resistance. Plant Physiol. 104:1109-1112.

68. Ryals, J., Weymann, K., Lawton, K., Friedrich, L., Ellis, D., Steiner, H.Y., Johnson, J., Delaney, T. P., Jesse, T., Vos, P., and Uknes, S. 1997. The Arabidopsis NIM1 protein shows homology to the mammalian transcription factor inhibitor $I_{K} B$. Plant Cell 9:425-439.

69. Shah, J., Tsui, F., and Klessig, D. F. 1997. Characterization of a salicylic acid-insensitive mutant (sail) of Arabidopsis thaliana, identified in a selective screen utilizing the SA-inducible expression of the tms 2 gene. Mol. Plant-Microbe Interact. 10:69-78.

70. Sierra, I., and Vidal-Valverde, C. 1999. Kinetics of free and glycosylated B6 vitamers, thiamin and riboflavin during germination of pea seeds. J. Food Sci. Agric. 79:307-310.

71. Sticher, L. Mauch-Mani, B., and Métraux, J. P. 1997. Systemic acquired resistance. Annu. Rev. Phytopathol. 35:235-270.

72. Strange, R. N. 1998. Plants under attack II. Sci. Prog. 81:35-68.

73. Uknes, S., Mauch-Mani, B., Moyer, M., Potter, S., Williams, S., Dincher,
S., Chandler, D., Slusarenko, A., Ward, E., and Ryals, J. 1992. Acquired resistance in Arabidopsis. Plant Cell 4:645-656.

74. Upreti, K. K., Das, M., and Khanna, S. K. 1991. Role of antioxidants and scavengers on argemone oil-induced toxicity in rates. Arch. Environ. Contam. Toxicol. 20:531-537.

75. Van Loon, L. C., Bakker, P. A. H. M., and Pieterse, C. M. J. 1998. Systemic resistance induced by rhizosphere bacteria. Annu. Rev. Phytopathol. 36:453-483

76. Van Wees, S. C. M., Pieterse, C. M. J., Trijssenaar, A., Van't Westende, Y. A. M., Hartog, F., and Van Loon, L. C. 1997. Differential induction of systemic resistance in Arabidopsis by biocontrol bacteria. Mol. PlantMicrobe Interact. 10:716-724.

77. Vaux, D. L., and Korsmeyer, S. J. 1999. Cell death in development. Cell 96:245-254.

78. Vernooij, B., Friedrich, L., Goy, P. A., Staub, T., Kessmann, H., and Ryals, J. 1995. 2,6-Dichloroisonicotinic acid-induced resistance to pathogens without accumulation of salicylic acid. Mol. Plant-Microbe Interact. 8:228-234.

79. Vernooij, B., Uknes, S., Ward, E., and Ryals, J. 1994. Salicylic acid as a signal molecule in plant-pathogen interactions. Curr. Opin. Biol. 6:275279.

80. Vijayan, P., Shockey, J., Lévesque, A. C., Cook, R. J., and Browse, J. 1998. A role for jasmonate in pathogen defense of Arabidopsis. Proc. Natl. Acad. Sci. USA 95:7209-7214.

81. Wang, S., and Tzeng, D. D. 1998. Methionine-riboflavin mixtures with surfactants and metal ions reduce powdery mildew infection in strawberry plants. J. Am. Soc. Sci. 123:987-991.

82. Ward, E. R., Uknes, S. J., Williams, S. C., Dincher, S. S., Wiederhold, D. L., Alexander, D. C., Ahl-Goy, P., Métraux, J.-P., and Ryals, J. A. 1991. Coordinate gene activity in response to agents that induce systemic acquired resistance. Plant Cell 3:1085-1094.

83. Wolinsky, I., and Driskell, J. A. D. 1997. Sports Nutrition: Vitamins and Trace Elements. CRC Press, Boca Raton, FL.

84. Xiang, C., and Oliver, D. J. 1998. Glutathione metabolic genes coordinately respond to heavy metals and jasmonic acid in Arabidopsis. Plant Cell 10:1539-1550.

85. Xie, D.-X., Feys, B. F., James, S., Nieto-Rostro, M., and Turner, J. G. 1998. COI1: An Arabidopsis gene required for jasmonate-regulated defense and fertility. Science 280:1091-1094.

86. Yang, Y., and Klessig, D. F. 1996. Isolation and characterization of a tobacco mosaic virus-inducible $m y b$ oncogene homolog from tobacco. Proc. Natl. Acad. Sci. USA 93:14927-14977.

87. Zhang, S., and Klessig, D. F. 1997. Salicylic acid activates a 48-kD MAP kinase in tobacco. Plant Cell 9:809-824.

88. Zhang, Y., Fan, W., Kinkema, M., Li, X., and Dong, X. 1999. Interaction of NPR1 with basic leucine zipper protein transcription factors that bind sequences required for salicylic acid induction of the $P R-1$ gene. Proc. Natl. Acad. Sci. USA 96:6523-6528.

89. Zhou, J., Loh, Y.-T., Bressan, R. A., and Martin, G. B. 1995. The tomato gene Ptil encodes a serine/threonine kinase that is phosphorylated by Pto and is involved in the hypersensitive response. Cell 83:925-935.

90. Zubay, G. 1998. Biochemistry. Brown Publishers, Dubuque, IA. 